\title{
The level of corporate social responsibility in Mexican franchises
}

\author{
Cesario Armando Flores Villanueva ${ }^{1}$ \\ Universidad Autónoma de Nuevo León \\ cesario.floresvl@uanl.edu.mx \\ María del Carmen Gaytán Ramírez ${ }^{2}$ \\ Universidad Autónoma de Nuevo León \\ maria.gaytanra@uanl.edu.mx
}

DOI: https://doi.org/10.21158/01208160.n85.2018.2046

\section{Fecha de recepción: 13 de febrero de 2018}

Fecha de aprobación: 06 de marzo de 2018

Cómo citar este artículo / To reference this article / Comment citer cet article / Para citar este artigo:

Flores Villanueva, C. A. y Gaytán Ramírez, M. C. (2018). The level of corporate social responsibility in mexican franchises. Revista EAN, 85, 15-35. DOI: https://doi.org/10.21158/01208160.n85.2018.2046

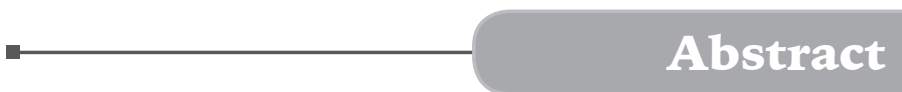

This research evaluates the level of corporate social responsibility activities by the application of 26 indicators grouped according to the following dimensions: environment, society, corporate management and products and services. Beginning with the analysis of 401 websites of franchises that are currently operating in Mexico, $22.9 \%$ really communicates corporate social responsibility activities. This hypothesis combines the theory based on resources, the theory of stakeholders and the theory of agency. Its regression outcomes indicate that the franchise age and the percentage of franchise chain units influence the level of corporate social responsibility activities in a negative way; meanwhile the size and the entry quote influence their level in a positive way.

\section{Key words}

Business social responsibility, franchises (small trading)- social aspects- Mexico, franchises (small trading)- environmental aspects- Mexico, franchises (small trading)- economic aspects- Mexico, sustainable development.

\footnotetext{
${ }^{1}$ Ingeniero Químico. Magíster en Relaciones Internacionales y Doctorado en filosofía con acentuación en Relaciones Internacionales, Negocios y Diplomacia por la Universidad Autónoma de Nuevo León.

${ }^{2}$ Licenciada en Ciencias de la Comunicación con acentuación en Mercadotecnia y Magíster en Relaciones Internacionales. por la Universidad Autónoma de Nuevo León. Estudiante de doctorado en filosofía con acentuación en Relaciones Internacionales, Negocios.
} 


\section{El nivel de responsabilidad social empresarial en las franquicias mexicanas}

Resumen. Esta investigación evalúa el nivel de actividades de responsabilidad social empresarial (RSE) mediante el uso de 26 indicadores agrupados en las dimensiones: medio ambiente, sociedad, gobernanza corporativa y productos y servicios. A partir de un análisis de los websites de 401 franquicias que actualmente operan en México, se encontró que solamente el $22.9 \%$ comunica sus actividades de RSE. El planteamiento de las hipótesis combinó la teoría basada en recursos, la teoría de los stakeholders y la teoría de la agencia. Los resultados de la regresión indican que la edad de la franquicia y el porcentaje de unidades franquiciadas en la cadena influyen negativamente en el nivel de actividades de RSE, mientras que el tamaño y la cuota de entrada influyen positivamente en el nivel de estas misma actividades.

Palabras clave: Responsabilidad social de los negocios, franquicias (comercio minorista) - aspectos sociales México, franquicias (comercio minorista) - aspectos ambientales - México, franquicias (comercio minorista) aspectos económicos - México, desarrollo sostenible.

\section{Niveau de responsabilité sociale et entrepreneuriale des franchises mexicaines}

Résumé. Cette étude évalue le niveau des activités de responsabilité sociale des entreprises (RSE) à l'aide de 26 indicateurs regroupés sous les thématiques suivantes: environnement, société, gouvernance d'entreprise, produits et services. L'analyse des 401 sites internet de franchises actuellement en activité au Mexique a révélé que seul 22.9 $\%$ des entreprises déclaraient leurs activités en matière de RSE. Notre approche associe la théorie des ressources, la théorie des parties prenantes et la théorie de l'agence. Les résultats de la régression indiquent que l'ancienneté de la franchise sur le marché et le pourcentage d'unités franchisées de la chaîne ont une influence négative sur le niveau des activités de RSE alors que la taille et le quota d'entrée ont une influence positive sur le niveau de ces activités.

Mots clefs: Responsabilité sociale des entreprises, franchises - aspect social - Mexique, franchises - aspects environnementaux - Mexique, franchises - aspects économiques - Mexique, développement durable.

\section{O nível de responsabilidade social empresarial nas franquias mexicanas}

Resumo. Esta pesquisa avalia o nível de atividades de responsabilidade social empresarial (RSE) mediante o uso de 26 indicadores agrupados nas dimensões: meio ambiente, sociedade, governo corporativo e produtos e serviços. A partir de uma análise dos websites de 401 franquias que atualmente operam no México, se encontrou que somente $22.9 \%$ comunica suas atividades de RSE. A proposta das hipóteses combinou a teoria baseada em recursos, a teoria de os stakeholders e a teoria da agência. Os resultados da regressão indicam que a idade da franquia e a percentagem de unidades franquiadas na cadeia influenciam negativamente no nivel de atividades de RSE, enquanto o tamanho e a quota primeiramente influenciam positivamente no nível destas mesma atividades.

Palavras-chave: Responsabilidade social dos negócios, franquias (comércio varejista) - aspectos sociais -- México, franquias (comércio varejista) - aspectos ambientais -- México, franquias (comércio varejista) - aspectos econômicos - México, desenvolvimento sustentável. 


\section{Introduction}

$\mathbf{N}$ owadays, more companies are concerned about the environment, the community life, and the social rights, and because of this, they are interested in including Corporate Social Responsibility practices (CSR) within their business management (Webb \& Honnen, 2006; Kaufmann, Bhattacharya, \& Hsu, 2008).

Corporate Social Responsibility (CSR) is defined as «a commitment to improve community well-being through discretionary business practices and contributions of corporate resources» (Kotler \& Lee, 2005, p.3). As Cuervo et al. (2008) mention, companies with CSR voluntarily commit themselves beyond their legal obligations, fulfilling an ethical commitment to society and the environment where they operate. Ergo is considered not only the company within borders, but also the one in connection with the interest groups that surround it, such as employees, customers, local communities, the environment, suppliers, and distributors (Lafuente et al., 2003).

Although CSR has been defined in many ways, consistently the notion of CSR includes: a) benefits to society in a way that it may not directly benefit the financial position of the company, and b) attention to the needs of the different parties interested in the organization or stakeholders (Basil \& Erlandson, 2008).

Freeman (1984) defines a stakeholder as: «any group or individual that can affect or be affected by the achievement of the objectives of the company» (Freeman, 1984, p.46). According to González Esteban (2007), there are three important points on the stakeholder theory that stand out. To begin with, it allows thinking of a business paradigm in which there is an understanding of the plural company, where each agent involved is affected by the organization. Secondly, each stakeholder has reciprocal expectations of behavior; also Hill and Jones (1992) mention that each of these groups -employees, customers, suppliers, communities- provides the company in some way, and they, in return, expect their interests to be satisfied. And thirdly, it is easy to observe the existence of CSR thanks to this theory, understanding it from an ethical sense on the part of the company.

To continue, Waddock and Graves (1997) grouped CSR activities into three categories, on the one hand inputs, on the other, internal behaviors and processes, and finally, outputs. Inputs refer to internal investment in socially responsible efforts, for example, pollution control. Internal behaviors and processes refer to procedures within the organization, which focus on the appropriate treatment of stakeholders. And, the outputs refer to behaviors that impact the stakeholders outside the company (Waddock \& Graves, 1997). In other words, the inputs and internal behaviors and processes have to do with internal business procedures, while outputs are related to external behaviors (Basil \& Erlandson, 2008).

The importance that companies are giving to CSR has been acquired because it can benefit them by achieving greater recognition and identification of their values (Comín, 2007); it is also essential for improving their reputation and creating a competitive advantage (Fombrun \& Shanley, 1990; Gatewood et al., 1993; Turban \& Greening, 1997; Freeman, 2006; Perrigot, Oxibar, \& Déjean, 2015). Another benefit of CSR is higher corporate financial performance (Griffin \& Mahon, 1997; Waddock \& Graves,




1997; Lee \& Faff, 2009); however, it should be mentioned that there is no consensus in the literature on this point, since the results of this relationship have mixed results.

Therefore, franchises as business organizations get involved in CSR practices, without even knowing they do, performing activities that benefit the stakeholders and the community: giving donations, participating and cooperating in educational, health, social inclusion issues; and also activities that benefit the environment and its employees, to name a few. According to Basil and Erlandson (2008) the different motivations to carry out CSR activities range from self-interest to true altruism. For example, in the study by Meiseberg and Ehrmann (2012), the authors reported that $75 \%$ of German franchisors stated that it is important to engage in CSR activities to improve financial performance and increase brand reputation and loyalty; $55 \%$ stated that it is important to increase the credibility of the brand image, and that the reasons for getting involved in CSR was to attract new franchisees and increase consumer spending. This same study revealed that the most used means to communicate the activities of CSR were the press releases and the corporate web pages.

The study of CSR in the franchising sector is justified by ethical reasons, also by the importance of the sector for the emerging economies and by the different sectors that adopt the franchise as a means to grow and compete in the market however, there are few works on this topic applied to the franchise system, which is why this topic should be examined in greater depth (Perrigot, Oxibar, \& Déjean, 2015).

The importance of the franchising sector in Mexico is manifested by the contribution of $6.5 \%$ of Gross Domestic Product (GDP), and the generation of 700,000 jobs according to the Mexican Association of Franchises. In the year 2016, Entrepreneur 500 Franchises magazine that annually reports the number of franchisors in Mexico, reported a list of 1,019 brands. Out of this figure, 899 brands are of Mexican origin and 120 of foreign origin, that is to say, $88.2 \%$ of the brands are of national origin. The franchises in Mexico operate in 13 different sectors, where food sector with $31 \%$, specialized services with $13 \%$, and specialized trade with $10 \%$ are the most important.

The different lines of research in franchising should be corroborated from different cultural contexts and different environments in developed countries (Baker \& Dant, 2008). This study contributes to expand this knowledge by evaluating the level of CSR in the franchising system in Latin American countries. Our research hypotheses are based on the theoretical perspectives of Resource as the Base Theory (RBT) and the stakeholder theory as the complementary one, and the concepts of agency theory that underlie the behavior of the franchisor - franchisee relationship.

This article aims at answering the question: What are the factors that determine the level of involvement of the franchise sector in Mexico in CSR activities?

This study was based on 92 franchise chains operating in the Mexican territory. The level of CSR activities reported on the corporate websites of these franchisors was analyzed using the content analysis technique. This paper is organized as follows: the second section describes theoretical supports and research hypotheses; the third section describes the methodology; the fourth section presents the results and their discussion, and finally, the conclusions. 


\section{Theoretical support and hypothesis}

$\mathbf{T}$

Theorists, Caves and Murphy (1976) define franchise as an agreement for a definite or indefinite period of time in which the owner of a trademark, called franchisor, guarantees to another person or firm, called franchisee, the right to operate under this trademark with the purpose of producing or marketing a product or service; where the franchisor and franchisee are legally independent, but economically interdependent (Michael, 2003). In this way, franchisors and franchisees collaborate to sell products and services.

Under the perception of the agency theory (Caves \& Murphy, 1976; Jensen \& Meckling, 1976; Carney \& Gedajlovic, 1991), agency problems arise when franchisees can act opportunistically. For example in the franchise, CSR practices contribute to the perception and reputation of the brand in front of the interest groups, but the cooperation and investment by the franchisees is fundamental for the implementation strategy and the diffusion of CSR practices in the local markets (Meiseberg \& Ehrmann, 2012; Perrigot, Oxibar, \& Déjean, 2015). However, the franchisee can act opportunistically on the right of the franchisor's reputation by reducing the quality of the product and the services that are offered (Michael, 2003) or by not participating in CSR practices.

The degree of involvement of the firm in CSR activities can be addressed through the Penrose's firm resource theory (Penrose, 1959). This theory asserts that the company possesses a number of valuable and hard-toimitate resources and capacities called strategic assets, which can be the source of long-term sustainable competitive advantage. Resources are divided into two fundamental categories: a) tangible resources, and b) intangible resources.
Tangible resources can easily be acquired by competing firms in the marketplace and can be easily imitated by competitors. Intangible assets such as copyrights, patents, designs, trademarks, and organizational structure are valuable and difficult to imitate (Galbreath, 2005).

Managers allocate resources to CSR activities on a cost-benefit basis (McWilliams \& Siegel, 2001), that is, companies behave in a socially responsible manner because they assume that it generates benefits such as: better reputation vis-à-vis consumers, hire and retain the best employees, or become more attractive to future franchisees (Meiseberg \& Ehrmann, 2012). Resources either acquired or developed internally by the firm, need the involvement of stakeholders. Managing resources involves managing relationships with stakeholders (Lebbos et al., 2017).

In the reputation of the franchises' brand, the operational routines, the routines of shared knowledge, and the inter-firm trust are strategic assets owned by the franchisor, that configure the decisions of the franchise on key strategic objectives, standardization, or adaptation. Both are essential, but each requires a different organizational form. Under this approach, the franchises that use the standardized practices of CSR as a source of competitive advantage will be formed by their owned units (Gillis, Combs, \& Ketchen, 2014). Age, experience, and size are often used as proxies to operationalize the accumulation of specific resources and competences of the franchises over time (Alon, 2000); and as the abundance of these resources differ between different companies (Pentrose, 1959), it is expected that the level of CSR will be different among the different franchises that make up the industry. 
This research addresses the involvement of franchises in CSR practices combining the resource-based theory (RBT) and the stakeholder theory (ST). As Lebbos et al. (2017) mention, although both theories use different approaches, they contain complementary aspects because: a) the importance of stakeholder relations management is recognized as an influential factor of organizational performance, survival, and effectiveness, since the interests of these groups or individuals can affect or be affected by the achievement of organizational objectives, b) managing internal and external relationships is essential to obtain competitive advantages based on resources, and c) the allocation of the firm's internal resources influences the implementation of the strategy to achieve a sustainable competitive advantage.

The theoretical foundation of CSR known as the stakeholder theory defines a stakeholder as «any group or individual that may affect or may be affected by the achievement of the objectives of the company» (Freeman, 1984, p.46). According to Freeman (1984), the stakeholders influence the administration of the companies and therefore, the directors must carry out their management as follows: first, one must understand from the rational perspectives, who the stakeholders of the organization are and what interests are observed. Second, the organizational processes that are implicitly or explicitly used must be understood in order to guide the relations of the organization with the stakeholders, and also whether these processes fit well with the organization's rational stakeholder map. And finally, it is necessary to understand the set of transactions or businesses between the organization and its stakeholders, and deduce again if these negotiations are adjusted with the map of stakeholders.

\subsection{The investigation of the Corporate Social Responsibility (CSR) in the franchise}

The works that address the topic of CSR in the franchise are limited. Table 1 shows the previous studies starting with the work elaborated by Kaufmann, Bhattacharya, and Hsu (2008). 
Table 1. Studies related to CSR in the franchise

\begin{tabular}{|c|c|c|c|}
\hline AUTHOR & OBJECTIVE AND SAMPLE & $\begin{array}{c}\text { CSR } \\
\text { DIMENSIONS }\end{array}$ & RESULTS \\
\hline $\begin{array}{l}\text { Kaufmann, } \\
\text { Bhattacharya, } \\
\text { and Hsu } \\
\text { (2008) }\end{array}$ & $\begin{array}{l}\text { In a sample of } 100 \text { franchise } \\
\text { systems in the US, they evaluated } \\
\text { the relationship between age, } \\
\text { number of company units, } \\
\text { investment per unit, proportion } \\
\text { of franchised outlets, and passive } \\
\text { ownership franchises and their } \\
\text { likelihood of engaging in positive } \\
\text { CSR activities, and the level of } \\
\text { those activities. }\end{array}$ & $\begin{array}{c}\text { Philanthropy, } \\
\text { Cause marketing, } \\
\text { Volunteerism and } \\
\text { Sponsorship. }\end{array}$ & $\begin{array}{l}\text { From the total of sampled } \\
\text { franchisors, } 29 \% \text { were involved } \\
\text { in some form of CSR activities. } \\
\text { Only the companies that owned } \\
\text { units and total investment had a } \\
\text { positive influence on the level of } \\
\text { CSR. }\end{array}$ \\
\hline $\begin{array}{c}\text { Meiseberg } \\
\text { and Ehrmann } \\
\text { (2012) }\end{array}$ & $\begin{array}{l}\text { A questionnaire was applied to a } \\
\text { sample of } 76 \text { German franchise } \\
\text { systems. This study examined the } \\
\text { influence of the characteristics of } \\
\text { the franchise system, industry, and } \\
\text { competitive factors that determine } \\
\text { the degree of chain-level CSR } \\
\text { activity and the influence of the } \\
\text { CSR level on the performance of } \\
\text { the franchise system. }\end{array}$ & $\begin{array}{l}\text { Support for the } \\
\text { community } \\
\text { Franchisee/ } \\
\text { Employee } \\
\text { relations } \\
\text { Environment } \\
\text { Human Rights } \\
\text { Products and } \\
\text { Services } \\
\text { Corporate } \\
\text { Governance }\end{array}$ & $\begin{array}{l}\text { The main reasons for engaging } \\
\text { in CSR activities are to attract } \\
\text { better franchisees and to increase } \\
\text { customer spending. They reported } \\
\text { that System Size, Multiunit } \\
\text { Ownership, and CSR experience } \\
\text { are positively related in CSR } \\
\text { intensity. The CSR intensity has } \\
\text { a positive effect on performance } \\
\text {-sales-. }\end{array}$ \\
\hline $\begin{array}{c}\text { Perrigot, } \\
\text { Oxibar, and } \\
\text { Déjean (2015) }\end{array}$ & $\begin{array}{l}\text { The determinants of corporate } \\
\text { social responsibility (CSR) report } \\
\text { in the franchising sector. The } \\
\text { empirical study conducted in } \\
\text { the French market, analyzes the } \\
\text { corporate social disclosure on } \\
\text { the website of } 136 \text { franchisors, } \\
\text { determining the relation between } \\
\text { chain size and the percentage of } \\
\text { units on CSR within the chain } \\
\text { owned by the company. }\end{array}$ & $\begin{array}{c}\text { Environment } \\
\text { Human resources } \\
\text { Products } \\
\text { Fair business } \\
\text { practices } \\
\text { Community } \\
\text { involvement } \\
\text { Ethics } \\
\text { Other }\end{array}$ & $\begin{array}{l}\text { In this study, } 86.03 \% \text { of } \\
\text { the sampled franchisors } \\
\text { communicate at least one of their } \\
\text { CSR activities. They reported } \\
\text { that there is a significant and } \\
\text { positive relationship between } \\
\text { the chain size, the percentage } \\
\text { of units within the chain owned } \\
\text { by the company on the extent } \\
\text { of Corporate Social Disclosure } \\
\text { (CSD). }\end{array}$ \\
\hline $\begin{array}{l}\text { Ki Lee at al. } \\
\quad(2016)\end{array}$ & $\begin{array}{l}\text { In a sample of } 216 \text { franchisees from } \\
\text { the South Korean market, this } \\
\text { study was carried out in order to } \\
\text { understand how Franchisor Social } \\
\text { Responsibility (FSR) influences the } \\
\text { perceptions of the franchisees, of } \\
\text { the franchisor, and their relational } \\
\text { responses -trust, satisfaction, and } \\
\text { long-term orientation- }\end{array}$ & $\begin{array}{c}\text { Economic } \\
\text { Legal } \\
\text { Ethical } \\
\text { Philanthropy }\end{array}$ & $\begin{array}{l}\text { Using a Structural Model, this } \\
\text { authors found that FSR has a } \\
\text { positive effect on the franchisor's } \\
\text { image, and on the confidence } \\
\text { of the franchisees. The study } \\
\text { confirms that the FSR through } \\
\text { the confidence of the franchisees } \\
\text { and the image influences long- } \\
\text { term orientation. }\end{array}$ \\
\hline
\end{tabular}

Source. Prepared by the authors. 


\subsection{Research hypotheses}

The use of capital for the provision of CSR activities is related to economies of scale. Economies of scale allow larger firms to have a lower average cost than smaller firms to provide themselves CSR attributes (McWilliams \& Siegel, 2001). As Doherty (2007) refers, franchisors use franchising as a way to grow faster and achieve economies of scale in order to overcome barriers to growth, mainly financial and human capital resources, and especially in the early stages of their life cycle (Lafontaine \& Kaufmann, 1994). Once they reach a critical size, they will have the financial and human resources to overcome these limitations (Carney \& Gedajlovic, 1991). The size is positively related to the financial and non-financial resources of the company (Alon, 2000), and this resourses allow adopting measures to improve the reputation (Meiseberg \& Ehrmann, 2012). The size of the chain is related to a large number of units that allow the franchisor to experience a positive cash flow, giving him greater resources and greater experience, and this will be a measure of his success (Carney \& Gedajlovic, 1991; Shane, 1996). Social responsibility entails costs, such as the purchase of environmentally friendly equipment and products, strict quality controls, safety, and environmental programs, among others. Resources are the means to fulfill these activities (Branco \& Rodrigues, 2006). Meiseberg and Ehrmann (2012) confirmed that there is a significant positive relationship between size and participation in CSR. Also, the agency theory predicts that as firms expand into geographically dispersed locations, direct observation costs increase, and therefore the use of franchised units is greater (Gillis, Combs, \& Ketchen, 2014). Larger franchises will be more visible to stakeholders, consumers, future national and international franchisees, suppliers, etc. In this way, the monitoring by the stakeholders will motivate the firm to get involved in CSR activities, since the satisfaction of the stakeholders influences the performance of the firm (Meiseberg \& Ehrmann, 2012). The size of the franchise is a proxy to operationalize the resources and competences of the franchisor over time (Alon, 2006). In summary, larger franchises related to a large number of units will have greater financial and human resources to enable them to allocate resources to CSR activities.

Hypothesis 1 (H1). The bigger the size of the franchise, the higher the level of CSR activities.

The experience gained through the years of operating as a franchise allows the franchisor to develop the management and coordination capabilities that facilitate its national and international expansion (Shane, 1996; Alon \& McKee, 1999). By increasing the experience, franchisors develop organizational and management skills in order to adapt to different cultural environments (Castrogiovanni, Combs, \& Justis, 2006). Experience is a capacity that represents an intangible resource of the company (Galbreath, 2005). In an organizational form such as the franchising system, the development of CSR practices can be more complicated because franchisees are independent entrepreneurs, who must be convinced and educated to invest and develop CSR practices (Perrigot, Oxibar, \& Déjean, 2015). Meiseberg and Ehrmann (2012, p.585) argue that the correct selection of franchises is essential for the adoption of CSR practices. Only the most experienced franchisors develop the skills to establish relationships with stakeholders -franchisees, consumers-, product of experimentation, and repetition (Meiseberg \& Ehrmann, 2012).

Therefore, the implementation of CSR policies involves the administration of trained 
human resources (McWilliams \& Siegel, 2001), and this organizational structure is an organizational asset (Galbreath, 2005). In this way, the franchisors with more years of experience are better prepared to carry out this process, unlike the franchisors with a few years in the market that will be more focused on growing and are likely not to allocate resources to CSR activities (Kaufmann, Bhattacharya, \& Hsu, 2008; Meiseberg \& Ehrmann, 2012). Age is a proxy related to resources and capabilities (Alon, 2006), and measures franchise experience (Castrogiovanni, Combs, \& Justis, 2006).

Hypothesis (H2). The older the franchise, the higher its level of CSR activities.

The franchise system involves the mixing of company-owned outlets under the company's government and franchised outlets under the operation of independent investors called franchisees. The choice of this hybrid structure operates, not only because one is better than the other, but also because the existence of one form has a positive influence on the other (Bradach \& Eccles, 1989). The companyowned outlets facilitate the diffusion of the innovation and help to increase the uniformity and standardization of the processes (Combs, Ketchen, \& Short, 2011; Nijmeijer, Fabbricotti, \& Huijsman, 2014), and the franchised outlets facilitate the learning and adaptation to the local markets (Combs, Ketchen, \& Short, 2011; Sorenson \& Sørensen, 2011). Both, adaptation and standardization are essential strategic assets, so a balance between company-owned outlets and franchised units is an organizational tool that franchisors use to leverage their strategic assets and compete successfully (Gillis, Combs, \& Ketchen, 2014).

The choice of a relationship between company-owned outlets and franchised units in the chain can influence the future strategic positioning of the chain (Piot-Lepetit,
Perrigot, \& Cliquet, 2014). The involvement in CSR is part of these strategic decisions, and this implementation should be easier with a structure that is based mainly on companyowned outlets since the managers of the owned outlets must follow the uniform and standardized policies that are established by the franchisor, unlike of the franchisee that as an independent entrepreneur must be convinced and educated. Perrigot, Oxibar, and Déjean (2015) support this argument by finding a positive significant relationship between the percentage of own units and CSR. In addition and according to the agency theory, the risk of opportunism on the part of the franchisee implies a greater task of supervision by the franchisor in order to ensure compliance with CSR activities in their localities. In summary, it will be more difficult for the franchisor to verify the efforts and fulfillment of the activities of CSR in franchise units, than in own units (Perrigot, Oxibar, \& Déjean, 2015).

Hypothesis 3 (H3). The lower percentage of franchised units in the chain, the higher the level of CSR activities.

As Galbreath (2005) refers, the most important intangible resources to achieve the company's results are reputation, image, and intellectual property. In the franchise, the intangible resources are associated by the reputation of the brand and its knowledge or know how, which are essential for their success. When a franchisor invests in the reputation of the brand, he will have a strong incentive to take advantage of this valuable resource to achieve a competitive advantage. Ki Lee at al (2016) confirmed that the adoption of CSR practices positively influences the image of franchise systems against their franchisees, and increases their confidence to maintain long-term relationships. The higher the franchisor's intangible assets -brand name capital-at the beginning of the contract period, 
the higher the rents generated by his know-how, and the higher the initial fees (Windsperger, 2001), thus franchisors will require the new franchisee to have a higher franchise fee that reflects the value of these assets (Combs \& Castrogiovani, 1994; Díez de Castro \& Rondán Cataluña, 2004).

An agency problem arises when franchisees can leverage the reputation of the system to offer inferior quality, which demerits the entire chain (Michael, 2003), performing actions that increase local profits at the expense of the franchisor's reputation (Combs, Ketchen, \& Short, 2011), for example not investing or participating in CSR activities. Shane (1996) points out that the opportunism of the franchisee can be reduced through a high initial investment, since the risk of losing their investment by canceling the contract inhibits opportunistic behavior. It is an incentive for the franchisee to act according to the franchisor's criteria.

Hypothesis 4 (H4). The higher the franchise fee, the higher the level of CSR activities.

\section{Method}

\subsection{Sample}

The Internet is increasingly becoming one of the main tools for CSR information disclosure (Wanderley et al., 2008; Tagesson et al., 2009). The work of Meiseberg and Ehrmann (2012) revealed that the means that are most commonly used by the German franchisors to communicate CSR activities were press releases and corporate web pages. This study shows that much of the information about CSR practices is communicated on the websites of the franchisors. Based on the above, we analyzed the corporate websites of the franchises operating in Mexico, in order to collect information on the different CSR activities in which they participate. The advantage of using the websites is due to the fact that very few franchises in Mexico produce an annual report on their CSR practices, since these reports are mainly directed at investors and authorities (Utgard, 2015).

Considering that franchises are privately owned, data availability is limited (Gillis \& Castrogiovanni, 2012); therefore, it is necessary to turn to secondary sources for the purpose of collecting the data. The sample was constructed during the month of November of 2016, using the Entrepreneur 500 Franchises magazine of the year 2016 as the main source of data. The usefulness of this magazine is that it annually reports data from the brands that operate in Mexico, and it has been used like a secondary source by others authors (Fable \& Welch, 1998; Lafontaine \& Oxley, 2001; Alba, 2010). These sources of information have also been used as reference data for research in other countries (Shane, 1996; Alon \& Mckee, 1999; Baena \& Cerviño, 2010). Since the information reported in Entrepreneur 500 Franchises (Entrepreneur, 2016) did not include complete data, mainly on franchised units, it was necessary to obtain these values by consulting the website of the Mexican Franchise Association, the website of each franchisor, and electronic journals specialized in franchising, such as topfranquicias. com, comprarfranquicia.mx, 100franquicias.com. $m x$. The task of working with several sources allowed us to debug discordant data before including them in the database. As a result, an initial sample of 401 franchises was obtained with complete information on franchise 
age, company age, size, percentage of units franchised in the chain, initial investment, royalties, franchise fee, and industrial sector.

Based on this information of the 401 franchises, each company's corporate website was analyzed through the content analysis technique to obtain information on CSR activities. It was possible to identify that only 92 franchises reported information about their CSR practices on their websites and 309 who did not. In this way the sample for our work is formed by 92 franchises operating in the Mexican market.

\subsection{Analysis of data}

We used a linear regression model in order to run all the factors together and evaluate whether the study variables influence the level of CSR. In order to rule out multicollinearity problems, the Variance Inflation Factor (VIF) and the conditioning index were checked. The values obtained for the VIF were less than two, and for the index of conditioning less than 24.6. The values for VIF and the conditioning index should be less than 5 and 30 to rule out multicollinearity problems; we did not find evidence of multicollinearity problems in the regression results (Hair et al., 2007, p.208-209). We checked the normality of the independent variables and the dependent variable, using the Kolmogorov-Smirnov test and the measures of asymmetry, kurtosis. Only the franchise fee variable met the criterion of normality. Considering this not normality, the natural logarithm was applied to the rest of the variables to improve asymmetry and kurtosis (Perrigot, Oxibar, \& Déjean, 2015). The percentage of the variable of franchised units did not change since the natural logarithm did not improve the measures of asymmetry and kurtosis.

\subsection{Dependent variable: CSR activity level}

In order to analyze the information of the CSR activities that each franchise reports on its corporate website, the indicators of measurement of CSR activities on website are described in table 2. These indicators and dimensions are supported by previous studies performed by Capron and Gray (2000); Mozas-Moral, Puentes-Poyatos, and BernalJurado (2014); Perrigot, Oxibar, and Déjean (2015) (based on Hackston \& Milne, 1996), and adapted to be applied to the specific study of franchises.

What was analyzed in each website was whether or not they contained information on the indicators developed in table 2 , coding them with «1» if they reported activities in an indicator, and «0» if they did not report any activity.

Kaufmann, Bhattacharya, and Hsu (2008) used four dimensions - philanthropy, volunteering, sponsorship, and marketing- to identify the CSR activities of US franchisors. These authors measured the level of CSR activity as the number of different activities in which each franchisor was involved, as a result, the higher the level of CSR activities reported, the higher the level of CSR activity. Perrigot, Oxibar, and Déjean (2015) used the categories environment, human resources, products, fair business practices, community participation, ethics, and others. In turn, these categories were divided into subcategories, when they found information on the franchisor's website; they identified the subcategory corresponding to the activity and systematically increased the value of the corresponding variable in a unit. For this research, we have used the number of different indicators where the franchise reports CSR activities as a measure of the level of CSR activities.

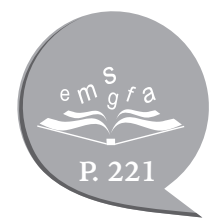


It is important to note that within a single indicator, some firms reported only one activity, while others participated in several activities that belonged to the same indicator. Following this criterion, the value «1» was reported only if it reported any activity in the indicator, regardless of the number of activities in each indicator, and «0» if it did not. In this way, the range of values of the CSR activity level varies from 1 to 26 according to table 2 . For example, if a franchise reports activities only to the water care indicator, it will have a CSR level equal to 1 . If another franchise reports activities related to the indicators of water care, support in health programs, and recycling of materials, it will have a CSR level 3.

Table 2. Indicators of measurement of CSR activities on website

\begin{tabular}{|c|c|c|}
\hline DIMENSIONS & INDICATORS & REFERENCES \\
\hline $\begin{array}{l}\text { Environment } \\
\text { It includes activities } \\
\text { related to climate change, } \\
\text { use of ecological products, } \\
\text { operations, and ecological } \\
\text { management. }\end{array}$ & $\begin{array}{l}\text { - Renewable energy use } \\
\text { - Recycling of materials } \\
\text { - Water care } \\
\text { - Information on emissions and waste discharge } \\
\text { - Use of organic products } \\
\text { - Certifications and / or prizes awarded for } \\
\text { environmental care. }\end{array}$ & $\begin{array}{c}\text { Capron \& Gray } \\
\text { (2000); Mozas-Moral, } \\
\text { Puentes-Poyatos, \& } \\
\text { Bernal-Jurado (2014); } \\
\text { Perrigot, Oxibar, and } \\
\text { Déjean (2015) (Based } \\
\text { on Hackston \& Milne, } \\
\text { 1996). }\end{array}$ \\
\hline $\begin{array}{l}\text { Society } \\
\text { It includes activities related } \\
\text { to human resources and } \\
\text { community involvement. }\end{array}$ & $\begin{array}{l}\text { - Use of risk prevention system } \\
\text { - Employee social benefits } \\
\text { - Employee training and education } \\
\text { - Certifications and / or awards for responsible labor } \\
\text { practices } \\
\text { - Local support in cultural activities } \\
\text { - Support in education programs } \\
\text { - Support in health programs } \\
\text { - Volunteer programs } \\
\text { - Awards for social actions } \\
\text { - Inclusion of groups } \\
\text { - Active participation of clients }\end{array}$ & $\begin{array}{c}\text { Capron \& Gray } \\
\text { (2000); Mozas-Moral, } \\
\text { Puentes-Poyatos, \& } \\
\text { Bernal-Jurado (2014); } \\
\text { Perrigot, Oxibar, and } \\
\text { Déjean (2015) (Based } \\
\text { on Hackston \& Milne, } \\
\text { 1996). }\end{array}$ \\
\hline $\begin{array}{l}\text { Products and services } \\
\text { It includes activities } \\
\text { related to quality and } \\
\text { detailed explanations } \\
\text { about the product or } \\
\text { service they offer. }\end{array}$ & $\begin{array}{l}\text { - Quality certifications } \\
\text { - Research and development reports } \\
\text { - Product labeling and service detail } \\
\text { - Warranty for product or service }\end{array}$ & $\begin{array}{c}\text { Mozas-Moral, } \\
\text { Puentes-Poyatos, \& } \\
\text { Bernal-Jurado, (2014); } \\
\text { Perrigot, Oxibar, and } \\
\text { Déjean, (2015) (Based } \\
\text { on Hackston \& Milne, } \\
\text { 1996). }\end{array}$ \\
\hline $\begin{array}{l}\text { Corporate Governance } \\
\text { It includes activities } \\
\text { related to the transparency } \\
\text { of the administration } \\
\text { and management of the } \\
\text { company. }\end{array}$ & $\begin{array}{l}\text { - Composition of the directors of the company } \\
\text { - Environmental impact policy reports } \\
\text { - Human resource policy reports } \\
\text { - CSR policy reports } \\
\text { - Others }\end{array}$ & $\begin{array}{l}\text { Capron \& Gray (2000); } \\
\text { Mozas-Moral, Puentes- } \\
\text { Poyatos, \& Bernal- } \\
\text { Jurado (2014). }\end{array}$ \\
\hline
\end{tabular}

Source. Prepared by the authors. 
The statement of mission, vision, and values was not included in this study and its communication normally contained general information, which did not emphasize on CSR practices. In addition, according to Utgard (2015), these principles are difficult to verify, inexpensive and their inclusion could influence outcomes, as opposed to activities related to processes and results that are costly and show the company's real involvement with CSR.

In order to guarantee the reliability of the codification, both authors independently identified the activities reported on the websites of each franchise. When there was a discrepancy in both counts, the type of activity, or the number of activities, the web page was revised again to correct the count. Differences were detected only in 12 websites of the franchises.

\subsection{Independent variables}

The age of the franchise represents the years that it has been operating as a franchise. The size represents the total units of the chain (Mariz-Pérez \& García-Álvarez, 2009; Meiseberg \& Ehrmann, 2012; Perrigot, Oxibar, \& Déjean, 2015). The percentage of franchised units represents the percentage of the franchised units of the total chain (PFUC) (Kaufmann et al., 2008; Mariz-Pérez \& García-Álvarez, 2009; Meiseberg \& Ehrmann, 2012; Gillis et al., 2014; Perrigot, Oxibar, \& Déjean, 2015). The franchise fee is the initial payment made by a franchisee to the franchisor for joining the chain; it is reported in thousands of Mexican pesos (Mariz-Pérez \& García-Álvarez, 2009; Perrigot, Oxibar, \& Déjean, 2015).

\subsection{Control variables}

In order to ensure that only the effect of the variable of interest is captured in the coefficient, control variables were used. This distinct behavior between sectors can be remedied by the use of control variables. This effect of the industry has been controlled in previous studies (Shane, 1998; Castrogiovanni, Combs, \& Justis, 2006). The most important sectors in the Mexican market were used as variables, from which we can name: the food sector, specialized trade, specialized services, and others -which is excluded from the regression and represents the base category-. The franchises that belong to a certain category were coded with «1», and with «0» if they did not belong to the category. The variable origin of the franchise has been controlled, codifying with «1» if it is national, and « $0 »$ if it is foreign. The age of the company that measures the years from the formation of the company was used as a control, since at older age it should have more owned units affecting the proportion of franchised units in the chain (Shane, 1998), besides influencing the size. 


\section{Results}

$\mathbf{T}$

The results revealed that out of the initial sample of 401 franchises analyzed, only 92 reported CSR practices, namely, $22.9 \%$ of the franchises reported participating in CSR practices in Mexico. On average, the participation is $3.46 \mathrm{CSR}$ activities of the indicators mentioned per franchise.

The results reported in Table 3 show that 315 activities were performed in 4 different dimensions. The most frequent activities correspond to the dimension of «Product and Service» (PyS for its abbreviation in Spanish) with a total of 118 frequencies $-37.5 \%$-; following the dimension of «Society» (S) with a total of 96 frequencies $-30.5 \%$-; The «Environment» dimension (E) is in the third place with a total of 72 frequencies -22.9 $\%-$; and finally, the dimension of «Corporate Governance» (CG) with a total of 29 frequencies $-9.2 \%-$.

At the same time, analyzing the indicators in Table 3, the most frequent activities were: firstly, «product labeling and product detailing» with a total of 55 frequencies -17.5 \%-; Secondly, «quality certifications» with 36 frequencies $-11.4 \%-$; in the third place, «active participation with customers» with 32 frequencies $-10.2 \%$-; in the fourth place with 25 frequencies $-7.9 \%$ - the activity of «use of ecological products»; and in the fifth position «product or service guarantee» with 20 frequencies $-6.3 \%$ -

Table 3. Frequencies and percentages of CSR activities reported on corporate franchise websites in Mexico

\begin{tabular}{|c|c|c|c|}
\hline DIMENSION & INDICATORS & FREQUENCIES & PERCENTAGES \\
\hline CSR LEVEL & Total & 315 & $100 \%$ \\
\hline \multirow{8}{*}{ Environment } & Renewable Energy use & 8 & $2.5 \%$ \\
\hline & Recycling & 12 & $3.8 \%$ \\
\hline & Water care & 12 & $3.8 \%$ \\
\hline & Emissions and waste discharge & 11 & $3.5 \%$ \\
\hline & Use of organic products & 25 & $7.9 \%$ \\
\hline & $\begin{array}{l}\text { Certifications or awards for care of the } \\
\text { environment }\end{array}$ & 4 & $1.3 \%$ \\
\hline & Sum & 72 & $22.9 \%$ \\
\hline & Employee risk prevention system & 1 & $0.3 \%$ \\
\hline \multirow{4}{*}{ Society } & Social benefits and employee development & 4 & $1.3 \%$ \\
\hline & Employee training & 7 & $2.2 \%$ \\
\hline & $\begin{array}{l}\text { Certifications or awards for responsible labor } \\
\text { practices }\end{array}$ & 2 & $0.6 \%$ \\
\hline & $\begin{array}{l}\text { Donations and/ or local support in cultural } \\
\text { activities }\end{array}$ & 11 & $3.5 \%$ \\
\hline
\end{tabular}


Table 3. Frequencies and percentages of CSR activities reported on corporate franchise websites in Mexico (Continuation)

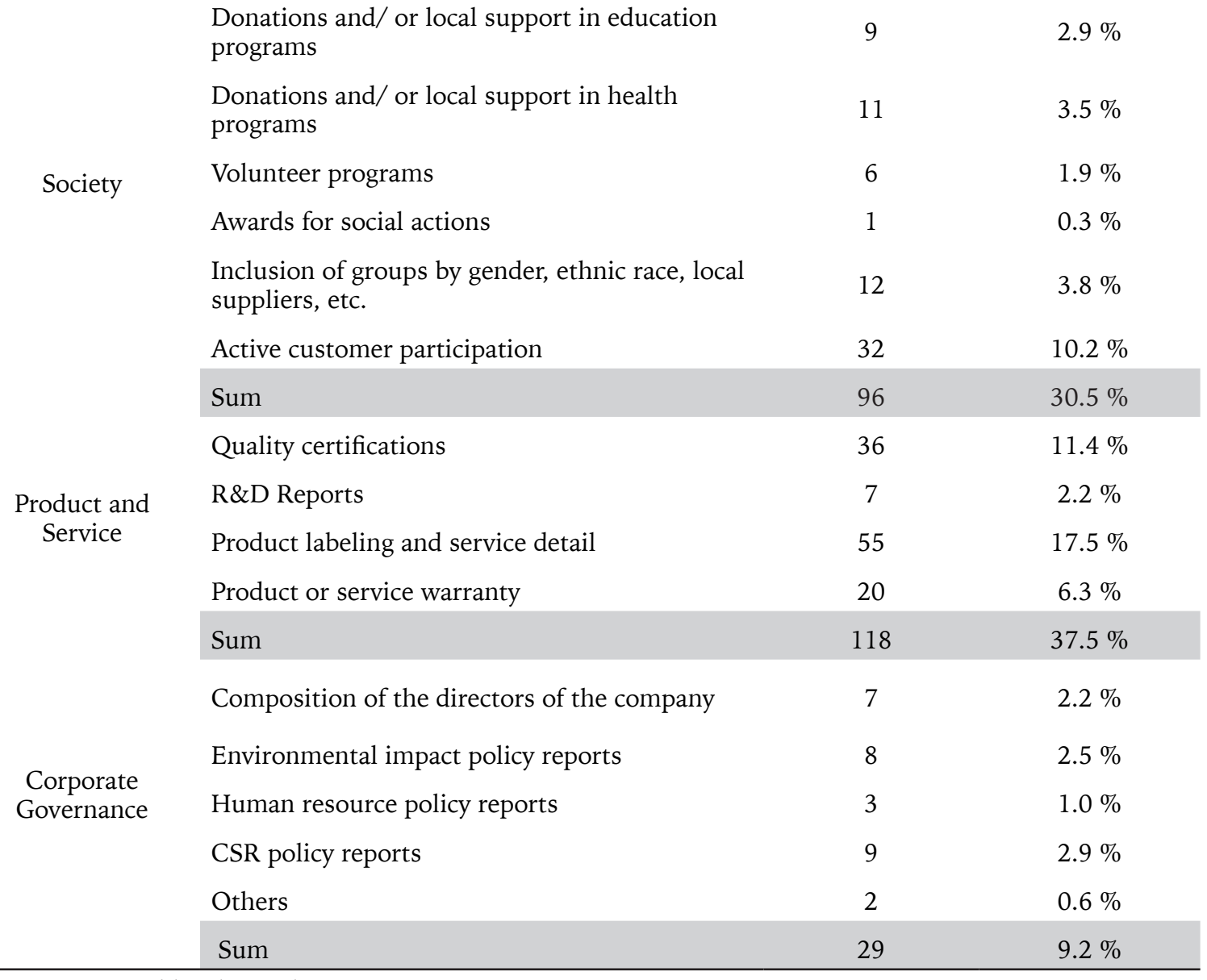

Source. Prepared by the authors.

Table 4 shows the descriptive statistics and correlations between the study variables. It is observed that the percentage of franchised units in the chain (PFUC) shows an average value of 69.5 and this variable individually maintains a significant negative correlation with the CRS level. The age and size of the franchise are correlated. On the other hand, the variable franchise fee is not correlated with any variable. 
Table 4. Table of descriptive statistics and correlations between the study variables

\begin{tabular}{|c|c|c|c|c|c|c|c|c|}
\hline VARIABLE & MEAN & STD. DEV. & 1 & 2 & 3 & 4 & 5 & 6 \\
\hline Ln (CRS Level) & 0.9753 & 0.70198 & 1 & & & & & \\
\hline Ln (Company age) & 3.0249 & 0.72627 & 0.045 & 1 & & & & \\
\hline Ln (Franchise age) & 2.3501 & 0.69701 & -0.115 & $0.550 * *$ & 1 & & & \\
\hline Ln (Size) & 3.5419 & 1.53716 & 0.188 & $0.458^{* *}$ & $0.459 * *$ & 1 & & \\
\hline PFUC & 69.4814 & 26.46532 & $-0.221^{*}$ & 0.014 & $0.211^{*}$ & 0.185 & 1 & \\
\hline Franchise fee & 358.8743 & 235.97758 & 0.162 & 0.107 & 0.178 & -0.177 & 0.077 & 1 \\
\hline
\end{tabular}

${ }^{* *} \mathrm{p}<0.01 * \mathrm{p}<0.05$ STD. DEV $=$ Standard Deviation

Source. Prepared by the authors.

Table 5. Results of the Linear Regression Model

\begin{tabular}{|c|c|c|c|c|c|}
\hline & Non-Standardized & Standardized & & \multicolumn{2}{|c|}{ Collinear Statistics } \\
\hline & B & $\mathrm{T}$ & Significance & Tolerance & VIF \\
\hline Food sector & -0.229 & -1.3 & 0.197 & 0.666 & 1.502 \\
\hline Specialized trade sector & 0.035 & 0.153 & 0.879 & 0.704 & 1.421 \\
\hline Specialized services sector & -0.127 & -0.663 & 0.509 & 0.645 & 1.55 \\
\hline Origin of the company & 0.056 & 0.272 & 0.787 & 0.737 & 1.357 \\
\hline Ln (Company age) & 0.026 & 0.207 & 0.837 & 0.53 & 1.888 \\
\hline Ln (Franchise age) & -0.316 & -2.487 & 0.015 & 0.574 & 1.741 \\
\hline Ln (Size & 0.206 & 3.741 & 0.000 & 0.63 & 1.586 \\
\hline PFUC & -0.006 & -2.266 & 0.026 & 0.789 & 1.268 \\
\hline Franchise fee & 0.001 & 2.819 & 0.006 & 0.774 & 1.292 \\
\hline Constant & 1.085 & 2.062 & 0.042 & & \\
\hline $\mathrm{R} 2$ & & & 0.249 & & \\
\hline R2 adjusted & & & 0.167 & & \\
\hline ANOVA & & & 3.027 & & \\
\hline Significance & & & & & \\
\hline
\end{tabular}

a. Dependent Variable: CSRLEVELNL Ln indicates the use of the natural logarithm

Source. Prepared by the authors. 
The results of the regression (table 5) show that the variable size of the franchise has a significant positive impact on the level of CSR $(b=0.206, p=0.00)$, confirming H1. The variable age of the franchise has a negative influence $(-0.316 ; \mathrm{p}=0.015)$ on the level of $\mathrm{CSR}$ rejecting $\mathrm{H} 2$. The variable percentage of franchised units has a negative influence on the level of CSR ( $b=-0.006 ; p=0.026)$ accepting $\mathrm{H} 3$. The variable franchise fee has a positive impact on the level of CSR ( $b=$ 0.001; $\mathrm{p}=0.006$ ) accepting $\mathrm{H} 4$.

When observing the control variables, none of them has any influence on the level of CSR.

\section{Discussion}

$\mathbf{P}$ elosa and Shang (2011) point out that some CSR activities have more positive impact than others on stakeholders, and that the motivations of some firms to invest in CSR practices are to create a social or environmental impact, not just to generate a financial performance. For Perrigot, Oxibar, and Déjean (2015), the determinant of spreading social responsibility in a company is a voluntary decision in many countries; what is sought is to meet the needs of the stakeholders and build a reputation supporting CSR activities. This could explain that only $22.9 \%$ of franchises in Mexico disseminate their CSR activities in corporate websites, as well as the fact that they voluntarily become involved in activities of this type.

Also, the high incidence of CSR practices in the «Product and Service»-37.5\%- and «Society»-30.5\%-dimensions reflects that the priority of CSR practices is concentrated on consumers and on the support to the society with the interest of the active participation of the customers, to achieve greater consumption and loyalty.

Meiseberg and Ehrmann (2012) point out that the experience in CSR -the time that the chain has been involved in CSR activitiesinfluences the intensity of CSR, nevertheless, in our study what was considered was the age of the franchise, not the experience in CSR. Meiseberg and Ehrmann (2012) revealed that the main reasons for CSR activities to be important for franchising are that they improve financial success, reputation, and brand loyalty, and they generate greater credibility of the brand image. They also reported that the involvement of franchisors in CSR is aimed at attracting better franchisees and at increasing the consumption of customers of their products and services.

These disclosures may indicate that younger franchisees in CSR practices consider greater involvement in CSR activities to improve their competitive position in Mexico. Using resources to engage in different CSR activities, instead of concentrating on a few activities seems to be the behavior of younger franchises to gain reputation and customer acceptance. Franchisors need to build a valuable brand in a relatively short time by opening as many outlets as possible (Michael, 2003), i.e. franchisors might consider a higher level of involvement in CSR practices as a valuable resource for gaining a reputation among the different stakeholders. In short, engaging in different CSR activities to serve different stakeholders and gain reputation, loyalty, and brand image is a competitive strategy used by younger franchises. 
This research corroborates that both financial and non-financial resources associated with size influence the CSR level. It is highlighted that franchisors consider that their assets are valuable and demand a high franchise fee to involve franchisees in CSR practices.

Franchisors often use company-owned stores to signal the value of their intangible assets
(Gallini \& Lutz, 1992). The results show that the involvement in CSR practices focuses mainly on the systems that maintain a majority owned outlets in the chain. Therefore, for Mexican franchisors it is essential to maintain control and reduce opportunism in order to implement CSR practices through their owned outlets.

\section{Conclusions and future lines of research}

$\mathbf{T}$ The results show that only $22.9 \%$ of the selected sample franchises practice and report on CSR-related activities. Older franchisors concentrate resources for CSR activities on few activities, while the younger franchisor in CSR practices focus on a greater number of activities to serve a larger number of stakeholders. This reasoning could be due to the fact that the smaller franchises compete in mature markets, where there is a great quantity of products, flavors, and services, so the need to differentiate through attributes of CSR is bigger (McWilliams \& Siegel, 2001).

Since the Mexican franchisors that are involved in CSR activities have a size that allows them to have resources to invest in CSR, they do so through their owned outlets where it is easier to monitor and follow CSR practices. The franchisors will be able to open their own premises in very visible places contributing to the reputation of the brand (Perrigot, López-Fernández, \& Eroglu, 2013). And it is possible that Mexican franchisors use CSR as a strategic exploitation of their resources to win this positive reputation. The contribution of this research is an additional knowledge to Mexican franchisors about the importance of CSR practices.

A future line of research should include: the influence of CSR practices on growth, financial results, and internationalization of franchising; in this way, the contribution would be greater knowledge about the benefits of CSR. 


\section{References}

Alba, C. (2010). Las franquicias en México en 1999 y 2007. Contaduría y administración, 230, 131-146.

Aldave, A., \& Cristina, M. (2010). Las franquicias en México en 1999 y 2007. Contaduría y administración, (230), 131-146.

Alon , I. (2006). When is Master International Franchising a Preferred Mode of Entry? In Service Franchising: A Global Perspective, 103-120. New York, NY: Springer Science + Business Media.

Alon, I. (2000). The organizational determinants of master international franchising. Journal of Business E Entrepreneurship, 12(2), 1-18.

Alon, I., \& McKee, D. (1999). Towards a macro environmental model of international franchising. Multinational Business Review, 7 (1), 76.

Baena, V., \& Cerviño, J. (2010). El efecto de la experiencia, tipo de actividad y renombre de marca sobre la expansión y grado de intensidad internacional de la franquicia española. Revista Española de Investigación de Marketing ESIC, 14(2), 6789.

Baker, B., \& Dant, R. (2008). Stable plural forms in franchise systems: An examination of the evolution of ownership redirection research. In Strategy and governance of networks, 87-112. Physica-VerlagHD.

Basil, D., \& Erlandson, J. (2008). Corporate social responsibility website representations: A longitudinal study of internal and external selfpresentations. Journal of Marketing Communications, 14(2), 125-137.

Bradach, J., \& Eccles, R. (1989). Price, authority, and trust: from ideal types to plural forms. Annual Review of Sociology, 15(1), 97-118.

Branco, M., \& Rodrigues, L. (2006). Corporate social responsibility and resource-based perspectives. Journal of business Ethics, 69 (2), 111-132.

Capron, M., \& Gray, R. (2000). Experimenting with assessing corporate responsibility in France: an exploratory note on an initiative by social economy firms. The European Accounting Review, 9(1), 99-109.
Carney, M., \& Gedajlovic, E. (1991). Vertical integration in franchise systems: agency theory and resource explanations. Strategic management journal, $12,607-629$.

Castrogiovanni, G., Combs, J., \& Justis, R. (2006). Resource scarcity and agency theory, predictions concerning the continued use of franchising in multi-outlet networks. Journal of small business management, 44(1), 27-44.

Caves, R., \& Murphy, W. (1976). Franchising: Firms, markets, and intangible assets. Southern Economic Journal, 572-586.

Combs, J. G., \& Castrogiovanni, G. J. (1994). Franchisor strategy: a proposed model and empirical test of franchise versus company ownership. Journal of Small Business Management, 32(2), 37-48.

Combs, J., Ketchen, D., \& Short, J. (2011). Franchising research: major milestones, new directions, and its future within entrepreneurship. Entrepreneurship Theory and Practice, 35(3), 413-425.

Comín, A. (2007). La responsabilidad social empresarial y la economía social. Cuadernos de Economía Social, 4, 1-6.

Cuervo, A., Fernández, A., Fernández, Z., Fernández, E., De la Fuente, J., Hernángómez, J., and others. (2008). Introducción a la administración de empresas. Arazándi S.A.

Díez de Castro, E., \& Rondán Cataluña, F. (2004). La investigación sobre franquicia. Investigaciones Europeas de Dirección y Economía de la Empresa, 10(3), 71-96.

Doherty, A. (2007). Support mechanisms in international retail franchise networks. International Journal of Retail \& Distribution Management, 35(10), 781-802.

Entrepreneur (2016, January). 500 franquicias. 20(01), 66-115.

Fable, C., \& Welch, D. (1998). Nafta and franchising: A comparison of franchisor perceptions of characteristics associated with franchisee success and failure in Canada, Mexico, and the United States. Journal of Business Venturing, 13(2), 151-171. 
Fombrun, C., \& Shanley, M. (1990). What's in a name? Reputation building and corporate strategy. Academy of management Journal, 33(2), 233-258.

Freeman, B. (2006). Substance Sells: Aligning Corporate Reputation and Corporate Responsibility. Public Relations Quarterly.

Freeman, R. (1984). Strategic Management. A Stakeholder Approach. Boston: Pitman.

Galbreath, J. (2005). Which resources matter the most to firm success? An exploratory study of resourcebased theory. Technovation, 25(9), 979-987.

Gallini, N., \& Lutz, N. (1992). Dual distribution and royalty fees in franchising. Journal of Law, Economics and Organization, 8, 471-501.

Gatewood, R., Gowan, M., \& Lautenschlager, G. (1993). Corporate image, recruitment image and initial job choice decisions. Academy of Management journal, 36(2), 414-427.

Gillis, W., \& Castrogiovanni, G. (2012). The franchising business model: an entrepreneurial growth alternative. International Entrepreneurship and Management Journal, 8(1), 75-98.

Gillis, W., Combs, J., \& Ketchen, D. (2014). Using Resource-Based Theory to Help Explain Plural Form Franchising. Entrepreneurship: Theory and Practice, 38(3), 449-472.

González Esteban, E. (2007). La teoría de los stakeholders. Un puente para el desarrollo práctico de la ética empresarial y de la responsabilidad social corporativa. Veritas. Revista de Filosofía y Teología, II(17), 205-224.

Griffin, J., \& Mahon, J. (1997). The corporate social performance and corporate financial performance debate: Twenty-five years of incomparable research. Business \& society, 36(1), 5-31.

Hackston, D., \& Milne, M. J. (1996). Some determinants of social and environmental disclosures in New Zealand companies. Accounting, Auditing \& Accountability Journal, 9(1), 77-108.

Hair, J., Anderson, R., Tatham, R., \& Black, W. (2007). Análisis Multivariante (5th ed.). Madrid: Pearson Prentice Hall.

Hill, C., \& Jones, T. (1992). Stakeholder-agency theory. Journal of Management Studies, 29(2), 131-154.
Jensen, M., \& Meckling, W. (1976). Theory of the firm: Managerial behavior, agency costs and ownership structure. Journal of financial economics, 3(4), 305-360.

Kaufmann, P., Bhattacharya, C., \& Hsu, L. (2008). Corporate Social Responsibility in Franchise Systems. Proceedings of the International Society of Franchising Conference.

Kotler, P., \& Lee, N. (2005). Corporate social responsibility. Hoboken.

Lafontaine, F., \& Kaufmann , P. (1994). The evolution of ownersip patterns in franchise. Journal of Retailing, 70(2), 97-113.

Lafontaine, F., \& Oxley, J. (2001). International franchising: Evidence from US and Canadian franchisors in Mexico. (No 8179). National Bureau of Economic Research.

Lafuente, A., Viñuales, V., Pueyo, R., \& Llaría, J. (2003). Responsabilidad Social Corporativa. Fundación Alternativas.

Lebbos , R., Amâncio-Vieira, S., Teruky , A., \& Spiri , T. (2017). A Convergência Entre Resource-Based View E Stakeholder Theory: Análise Bibliográfica Dos Acervos Dos Principais Periódicos Internacionais. Revista de Administração da UNIMEP, 15(2), 181-213.

Lee, D., \& Faff, R. (2009). Corporate sustainability performance and idiosyncratic risk: A global perspective. Financial Review, 44(2), 213-237.

Lee, K. H., Herold, D. M., \& Yu, A. L. (2016). Small and medium enterprises and corporate social responsibility practice: a swedish perspective. Corporate Social Responsibility and Environmental Management, 23(2), 88-99.

Mariz-Pérez, R., \& García-Álvarez, T. (2009). The Internationalization Strategy of Spanish Indigenous Franchised Chains: A Resource-Based View. Journal of Small Business Management, 47(4), 514-530.

McWilliams, A., \& Siegel, D. (2001). Corporate social responsibility: A theory of the firm perspective. Academy of Management Review, 26(1), 117-127.

Meiseberg, B., \& Ehrmann, T. (2012). Lost in translation? The prevalence and performance impact of corporate social responsibility in franchising. Journal of Small Business Management, 50(4), 566-595. 
Michael, S. (2003). First mover advantage through franchising. Journal of Business Venturing, 18(1), 6180.

Mozas-Moral, A., Puentes-Poyatos, R., \& BernalJurado, E. (2014). Spanish Second-Tier Cooperative Societies: An Analysis of E-Corporate Social Responsibility. Journal of Rural Cooperation, 42(1).

Nijmeijer, K., Fabbricotti, I., \& Huijsman, R. (2014). Making franchising work: a framework based on a systematic review. International Journal of Management Reviews, 16(1), 62-83.

Peloza, J., \& Shang, J. (2011). How can corporate social responsibility activities create value for stakeholders? A systematic review. Journal of the academy of Marketing Science, 39(1), 117-135.

Penrose, E. (1959). The Theory of the Growth of the Firm. New York: John Wiley.

Perrigot, R., López-Fernández, B., \& Eroglu, S. (2013). Intangible Resources and Plural Form as Drivers of Franchise Internationalization: Examination within a Two-Country Perspective. Journal of Small Business Management, 51(4), 557-577.

Perrigot, R., Oxibar, B., \& Déjean, F. (2015). Corporate Social Disclosure in the Franchising Sector: Insights from French Franchisors' Websites. Journal of Small Business Management, 53(2), 321-339.

Piot-Lepetit, I., Perrigot , R., \& Cliquet, G. (2014). Organizational form and efficiency of franchise chains. International Journal of Retail \& Distribution Management, $42(7), 671$ - 684.

Shane, S. (1996). Hybrid organizational arrangements and their implications for firm growth and survival: a study of new franchisors. Academy of Management Journal, 39(1), 216-234.

Shane, S. (1998). Explaining the Distribution of Franchised and Company-Owned Outlets in Franchise Systems. Journal of Management, 24(6), 717-739.
Sorenson, O., \& Sørensen, J. (2011). Finding the right mix: Franchising, organizational learning, and chain performance. Strategic Management Journal, 22(6-7), 713-724.

Tagesson, T., Blank, V., Broberg, P., \& Collin, S. (2009). What explains the extent and content of social and environmental disclosures on corporate websites: a study of social and environmental reporting in Swedish listed corporations. Corporate Social Responsibility and Environmental Management, 16(6), 352-364.

Turban, D., \& Greening, D. (1997). Corporate social performance and organizational attractiveness to prospective employees. Academy of management journal, 40(3), 658-672.

Utgard, J. (2005). Retail Chains' Corporate Social Responsibility Communication. Journal of Business Ethics, 1-16.

Utgard, J. (2015). Organizational form, local market structure and corporate social performance in retail. (Doctoral Thesis). Norweigan Business School.

Waddock, S., \& Graves, S. (1997). The corporate social performance-financial performance link. Strategic management journal, 303-319.

Wanderley, L., Lucian, R., Farache, F., \& de Sousa Filho, J. (2008). SR information disclosure on the web: a context-based approach analysing the influence of country of origin and industry sector. Journal of business ethics, 82(2), 369-378.

Webb, T., \& Hohnen, P. (2006). Corporate Responsibility-The connected world in 2006. Ethical Corporation.

Windsperger, J. (2001). The fee structure in franchising: a property rights view. Economics letters, 73(2), 219226. 
